\section{超電導と NMR}

国立研究開発法人物質・材料研究機構 強磁場ステーション長

清水 禎

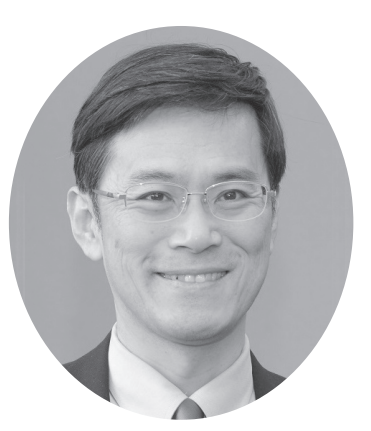

MRI（核磁気共鳴画像法）を含めた広い意味での NMR （核磁気共鳴法）は, 現代社会を支える不可欠の分析装置 であると同時に超電導産業の最大市場でもあることから, NMR と超電導は互いに特別の関係と言えます。この特別 の関係について NMR 屋としての立場も持つ私が日頃から 感じていることを述べさせていただきます。

NMR は 1945 年に発明されて，それから暫くの間は $1 \mathrm{~T}$ 程度の電磁石が用いられていました。今日の NMR で は当たり前になっている複雑な分子構造の解析は, 電磁石 では不可能であり，超電導磁石が必須です。NMR が超電 導磁石でなければ困る一番大きい理由は, その優れた磁場 安定度です。強い磁場が出せることも超電導磁石の特徴の 一つではありますが, 磁場強度は約 1 桁程度の優位に過 ぎないのに対して, 磁場安定度の方は約 4 栴ほど優れてお り, 電磁石ではどう頑張っても達成できない安定度を提供 しています。

NMR が高い磁場安定度を必要とする理由は, NMR の信 号強度が極端に弱いからです。つまり，弱い信号を貯めて 大きくするために長い積算時間を必要とするからです。も し将来，飛躍的な技術革新があって NMR の信号強度が何 桁も強くなれば高い磁場安定度も超電導磁石も不要になる かもしれませんが, そうならない限り超電導磁石と NMR の特別な関係は永続すると思われます。

超電導磁石の磁場安定度が高い理由は永久電流のお陰で すが, 超電導なら永久電流は当たり前かというと, 決して そういう訳ではありません。製造できる 1 本の超電導線の 長さに限界があるために, NMR 磁石のような大型の磁石 を作るには 1 本の超電導線では足りません。そこで 2 本ま たはそれ以上の超電導線をつないで必要な長さの 1 本を 作る必要がありますが, NbTi 以外の超電導体では超電導 接続の技術が不完全なので, 磁場の強い磁石ほど永久電流 の質が低下します。

特に顕著なのが高温超電導体です。 $1000 \mathrm{MHz}(23.5 \mathrm{~T})$ 以上の磁場を発生させるには高温超電導体を使うことが不 可避ですが, 高温超電導体は超電導接続が未開発のため,
永久電流が実現できません。永久電流でない磁石は, 固 体 NMR 測定には支障ありませんが，溶液 NMR には不十 分です。溶液 NMR は固体 NMR よりも分解能が約 3 桁以 上高い必要があるので磁場の不安定による影響を受けや すいからです。溶液 NMR はタンパク質の解析に重要なの で, $1000 \mathrm{MHz}$ を超える強磁場の溶液 NMR 磁石を開発す るには高温超電導体の超電導接続を解決することが不可避 です。

超電導の専門家ではない私のような者が申し上げるのは 差し出がましく, 誠に僭越とは思いますが, NMR 屋の立 場（超電導を利用させていただく側）から感じたままを述 べさていただくと, 超電導のバルクや線材の研究開発に比 べると, 超電導接続の研究開発はあまり活発ではないよう に見受けられ, 残念に思っています。非常にハイリスクの 研究テーマであるとは思いますが, 高温超電導体の超電導 接続を発明した人（会社, 国）が NMR 磁石製造の主導権 を握ることになると言っても過言ではないので, 開発を促 進する何か良い方法が出てくることを期待しています。

もちろん，ひたすら強い磁場へ突き進むことだけが, NMR の適切な発展であるとは言い切れません。電子顕微 鏡の分野では長年にわたり, 電子の加速電圧を上げること が分解能向上の唯一の方法だとの思い込みがあり, その結 果, 主に日本を中心に大型化の一途をたどっていました。 しかし，1990 年代後半から収差補正レンズが欧州で開発 されたことにより, 装置が劇的に変わると同時に市場主導 権が一変してしまいました。収差補正レンズを実現させた 技術要因はコンピュータが進歩したお陰なので, 誰にでも 発明のチャンスはあったはずなのですが，その狙いや発想 が多くの専門家にはなかったことが指摘されています。

NMR が普及するにつれて, 利用者側のニーズが多様化 してきており, 強磁場以外にも, 超大口径, 超小型, 超低 磁場, メンテナンスフリー等々の新しい要望が出てきてい ます。NMR は電子顕微鏡とは事情が異なるかもしれませ んが, 全員が同じことを目指すのではなく, 多様な価值観 に気付く「ゆとり」は大切なことであろうと思う次第です。 